Nicole Fayard*

\title{
Je suis Shakespeare: The Making of Shared Identities in France and Europe in Crisis ${ }^{1}$
}

\begin{abstract}
This essay investigates the ways in which Shakespearean production speaks to France and wider European crises in 2015 and 2016. The Tempest and Romeo and Juliet were directed by Jérôme Hankins and Eric Ruf respectively in December 2015 and reflected significant contemporaneous issues, including: (1) two Paris terrorist attacks which sent shock waves throughout France and Europe; (2) the belief that shared identities were under threat; (3) concerns over shifting power dynamics in Europe. The portrayal of these issues and their reception bring into question the extent to which cultural productions can help to promote social change or shape perceptions of national and pan-European events. This essay focuses on whether the plays successfully complicate binary narratives around cultural politics in a context of crises by creating alternative representations of difference and mobilities. It concludes that appropriating Shakespeare's cultural authority encourages some degree of public debate. However, the function of Shakespeare's drama remains strongly connected to its value as an agent of cultural, political and commercial mobility, ultimately making it difficult radically to challenge ideologies.
\end{abstract}

Keywords: Shakespeare in France; Eric Ruf; Jérôme Hankins; Cultural production and social change; European crisis; Heterotopia; Shakespeare myth; Postcolonialism.

This article investigates the ways in which Shakespearean production speaks to France and wider European crises in 2015 and 2016. I examine two performances of The Tempest and Romeo and Juliet directed by Jérôme Hankins and Eric Ruf respectively in December 2015. These productions corresponded with two Paris terrorist attacks which sent shock waves throughout France and Europe. The portrayal of such significant issues in the plays brings into question the extent to which cultural productions can help to promote social change or shape public debate. How does performing Shakespeare's theatre today influence the audience into having meaningful thoughts and conversations about

* University of Leicester, UK.

${ }^{1}$ Nicole Fayard wishes to thank the University of Leicester for a period of study leave during which this article was written. 
their own lives? Can it be argued that it contributes to the construction of contemporary collective identities?

Lay and State Islamophobia surged in France following the 2015 terrorist attacks as well as support for the far-right party the Front National. This helped the party to achieve a record number of votes in the regional elections of 2015 and caused a democratic crisis in the 2017 presidential elections opposing current President Emmanuel Macron to Front National leader Marine Le Pen. Similarly, populist parties with anti-European policies further prospered in most European member states as resentment against Germany's austerity policies, Europe's weak leadership and rejection of cultural differences fuelled distrust against the Union. Hankins explicitly linked his production with the killings: "comment travailler dans une salle de spectacle après les massacres du Bataclan?" (how can we put on a show following the slaughter in the Bataclan?) (Thiébault). Critics likewise reflected on the relationship between Ruf's production and "cet instant, après le 13 novembre, en plein choc électoral" (today, after November 13, as we reel from the shock of the elections) (Bouthors). The content of these productions therefore reflected major tensions over 2015-16, firstly between the need to negotiate cultural difference and the belief that shared-i.e. hegemonic-identities were under threat. Secondly, they underscored the contemporaneous shifting power dynamics within the European project, especially the undermining of the core principles of free movement and "unity in diversity" that define Europe's identity (Bigo et al.).

I shall principally focus on the ways in which Hankins' and Ruf's productions might have succeeded (or not) in complicating binary narratives around cultural politics in a context of crises. This tentative breaking-down of tropes entail the creation of sites of distortion or liminality, maybe suggesting alternative meanings and representations of difference and mobilities. These would be welcome outcomes, to be read in the light of Homi Bhabha's concept of interstitial or third spaces defined as sites where new identity projects could develop and explicitly challenge established constructions of cultural identities (Bhabha "Frontlines", 2). Likewise, Foucault's heterotopias-cited by Ruf as defining principles in his work-offer self-reflexive spaces that mirror, refract or warp reality (Foucault 24). Examining the development of alternative meanings would thus help to consider the role played by theatrical productions in commenting on and shaping perceptions of national and pan-European events. Performance and social change have long been bound together, and have stimulated scholarship and artistic practice since the late twentieth century (Corey 1; Landy and Montgomery). Kushner, Burnham, Fung and Paterson $(62,66)$ highlight the ability of the theatre to cast light on injustices and marginalization, whilst Greene and Kondo (Kushner 77) write about the power of art and performance to transform society by articulating progressive alternative possibilities and "construct[ing] political subjectivities that promote 
political change." Relying on Homi Bhabha's analysis of cultural identity and Foucault's heterotopias, I therefore intend to examine interpretative and scenic distortions in both productions as well as the ideological values they underscore, more specifically when issues of mobility, difference and exclusion are involved. This will help address the ways in which the plays might be agents for change or engagement. I also problematize these concepts by examining the role played by the signifier Shakespeare in the construction of these third spaces of renegotiation in the light of Roland Barthes's Mythologies and Emile Durkheim's cultural logic of collective representations. I conclude that the function of Shakespeare's drama in these productions is, in fact, more likely to be connected to Shakespeare's value as an agent of cultural, political and commercial mobility than, ultimately, to help radically to challenge ideologies or promote fundamental social change. Nevertheless, audience reception of both plays suggests that appropriating Shakespeare's cultural authority encouraged some degree of public debate.

\section{Shakespeare and the Politics of Mobility}

Let's begin with an anecdote located outside of Europe. In June 2017, a mere six months after the election of US president Donald Trump, right-wing protesters attempted to "shut down" a Central Park production of Julius Caesar in New York. For the British daily The Guardian, both the show and the campaign against it had clear political motives: "The protest was aimed at an artistic decision to set the play in a modern political setting, with Caesar looking decidedly like Donald Trump. As in every production of the play in the 418 years since it debuted, just as happened in 44BC, Caesar is assassinated." (Wahlquist and Beckett). The press further commented on the director's request to the actors to resume the play on the line "Liberty! Freedom!" (Wahlquist and Beckett). The production was part of a strategy sponsored by social media, and director Oskar Eustis fully expected a political backlash. Right on cue, the controversy surrounding the show caused it to be condemned by Fox News and led to two corporate sponsors withdrawing their financial support. A report by Fox News entitled "NYC Play Appears to Depict Assassination of Trump" suggested that Caesar/Trump was "brutally stabbed to death by women and minorities", and omitted to mention until the end of the feature that the play had been written by Shakespeare in the sixteenth century rather than being designed as a new anti-Trump work (Beckett). Following a shooting at a charity baseball game in Virginia, Donald Trump Jr. went as far as suggesting on Twitter that there were links between the NYC play and the murders. Significantly, the timeframe of this process overlapped with the controversy over President Trump's travel ban in place since December 2016. Immigration had been the 
main focus of the president's campaign, and the policy-barring visitors from seven majority Muslim countries from entering the country for ninety dayswas perceived as divisive on human and civil rights grounds (Laughland).

What makes this example fascinating is its concurrent association of "Shakespeare" with both sides of the ideological spectrum of the politics of migration and mobility. Using Shakespeare's drama to mirror national and global concerns is certainly not a new phenomenon. Thus, Shakespeare has long been perceived as a symbol of European cultures (including countries across the British Empire), and such symbols are crucial in the creation of integrated economic and political communities. The global circulation and mobility of his plays (via publishing, translation, theatre performance or digital products) follows the construction of collective representations of national and supranational identities: it is primarily an economic and cultural product that is controlled by social and ideological needs. As such, it helps maintain social hierarchies and systems of exclusions around national and supranational unity, difference, integration, and mobilities. In The Rules of Sociological Method (xliv), Emile Durkheim defined collective representations or myths as abstractions devised by social groups to reflect the values of society and spur people into action. Collective representations are invested with authority, and their role is to regulate behaviour. They rely on totems or systems of beliefs and rites which unify and bind the social group together around a sacred object (Durkheim xlix). Examples of familiar totems around which groups identify include national identity and values, the national flag and currency-or Shakespeare. Durkheim adds that the role and therefore invocation of totems is prominent in intense moments in history, such as the Second World War, the adoption of the Euro or terrorist attacks, all leading in their aftermath to reconstructions of the cohesive nation or group of nations. In Mythologies, published some sixty years after Durkheim in 1957, French semiologist Roland Barthes reflected on the ways in which contemporary social value systems build on language to create modern myths. Everything can be myth, and myths serve to reproduce models of national and collective identity. Importantly, the historical process which has led to their creation is rendered invisible. Thus, using Shakespeare as a sacred myth would also mean that his name and his theatre fulfil very specific ideological needs. For Barthes (Mythologies, 223) myth is conservative and helps to preserve the cohesion of the group. Besides, myths conveniently hide the utilitarian nature of the constructions that they incarnate, such as the economic and political function of mobilities. According to Durkheim, the totem is not only holy to the believer, but is part of the holy itself. This means the totem also becomes part of the ritual. These constructions also conceal the fact that the values we ascribe to myths are the products of power struggles. Amongst these is hidden the fetish of colonialist discourse: the very nature of myths causes cultures to be perceived as coherent entities rather 
than elements of a wider network of power relations. This necessary process of concealment plays an important role in the silencing of voices claiming to be different or unequal. Therefore, belief in the myth serves to conserve the social order. $^{2}$

The anecdote I offered above illustrates the extent to which, as a highly prized ideological fetish and cultural commodity, Shakespeare's drama can be encoded to shape constructions of migration and mobilities. This is important, as Geographer Tim Cresswell (22) has suggested that "there seems little doubt that mobility is one of the major resources of $21^{\text {st }}$-century life and that it is the differential distribution of this resource that produces some of the starkest differences today." Mobility involves the movement of people, ideas and commodities (such as Shakespeare). It is regulated by multilateral political and economic agreements as well as ideological conflicts. For Cresswell (18), the politics of mobility entails "entanglements of physical movement, representation, and practices". Importantly, human mobility is embodied, either within actual processes of physical movement or stasis. It is also discursively constituted through its various past and current representations-as when migrants from specific countries are constructed as putative terrorists-, and therefore involved in the production of complex power relations (Cresswell 20-22). As highlighted by Foucault (23), the concern with mobility is also reflective of twentieth and twenty-first century societies' intense preoccupation with space: how to measure, appropriate and control it, and also how to situate oneself within it. Thus, mobility relies on hierarchies and involves human, financial and environmental costs. The extent of these costs came to the fore during the so-called "European crisis" and its connections with the governance of mobility.

In 2015, France declared a state of emergency following two terrorist attacks orchestrated by ISIS in Paris. The first of these attacks made twelve victims in January at the headquarters of the satirical newspaper Charlie Hebdo and seventeen victims in total on separate sites. In November of that year a further 130 young people died at the Paris nightclub Le Bataclan. The timing of these attacks in the midst of the recent European crisis is important. Although the causes of the crisis are multidimensional, it was exacerbated by the sudden escalation of migration into Europe of asylum seekers from the Middle-East, Pakistan and Africa in 2015-16 (Buonano 102). The inability of EU leaders to manage the situation revealed deepening divisions between member states as some closed their borders to refugees. Following revelations after the killings in Paris that the terrorists had entered Europe illegally via Greece, Europe's security and justice policies became heavily contested. European and national leaders reframed the immigration crisis as a critical internal security threat as

\footnotetext{
${ }^{2}$ See also Bourdieu, as well as Fayard for an analysis of the Shakespeare myth in France.
} 
electoral challenges from far-right parties and increased anti-immigrant sentiment within public opinion flourished (Buonano 107). Communications around the refugee crisis of 2015 strategically and linguistically associated European identity with the idea of space, defining mobilities and migration in geographical terms such as "relocation", "hotspots" and "border control" (Commission européenne). Narratives represented migration and uncontrolled movement within Europe as a "crisis" causing the "destabilization" of "our own societies" and the very idea of Europe (Boitiaux). The founding principles of mobility and diversity in the "new" Europe thus overtly shifted towards the spatial redrawing of Europe from an open to a closed space designed to keep out the body of the Other in movement perceived as a threat to collective unity.

This redefinition of the group around a framework of national and supranational European unity, integration and exclusions typifies the construction of collective representations (Durkheim). The concept of Europe, like the concept of the nation, is built on imagined communities that rely on discursive constructs to uphold their symbolic values (Anderson 46). In the case of Europe, these constructions are based on the idea that there is a need to preserve a European consciousness, rooted in symbols and ideas about what Europe used to be and what it should be, drawn from various sources such as history, culture, literature, interpretations of political ideologies (Pagden). Europe is a concept with multiple incarnations, frequently associated with appeals to higher moral values and disinterestedness such as Europe as the land of human rights and civilization. Thus the motto of the European Union, "Unity in diversity" (European Union), is one of the rituals whereby Europe seeks to give itself an identity. Importantly, this motto both acknowledges and disavows processes of exclusion by outlining the rules of inclusion.

These rituals were illustrated in President Hollande's speech to the French nation condemning the 2015 terrorist attacks, in which he declared France to be at war with the terrorists and called for stringent border controls in France and Europe (Hollande). Whilst stressing the core values of the French Republic "which makes no distinction as to color, origin, background, religion" (Hollande), Hollande asserted France's:

détermination à défendre la liberté au jour le jour, c'est-à-dire la volonté de faire de la France un grand pays, fier de son Histoire, de son mode vie, de sa culture, de son rayonnement, de son idéal universel, du respect et même de la ferveur que notre pays inspire au monde chaque fois qu'il est blessé (France's determination to defend freedom day after day, that is to say, the will to make France a great country, proud of its history, its way of life, its culture, its influence and of its universal ideal, proud of the respect and even the fervour that our country inspires in the world every time it is wounded) (Hollande). ${ }^{3}$

${ }^{3}$ All translations are mine unless otherwise specified. 
These values were strongly supported with the "Marche républicaine" of 11 January 2015, a rally for national unity known as the French march for freedom in the English-speaking world, during which the defence of freedom of speech was illustrated with the widespread use of the slogan "Je suis Charlie" (I am Charlie). And yet these appeals to national cohesion and citizenship remained based on the grand narrative of civilization which dominated Hollande's references to the terrorists as "barbaric" "foreign fighters" and "cowardly" "enemies of Europe" (Hollande). Against these negatives, Hollande opposes the positive values of the French nation-state defined inclusively as "our democracy" and "our Republic". However the nation-state is also defined exclusively in the singular as only one culture and one way of life. In post-colonialist terms, the aim of such familiar oppositions between a dominant ingroup that views itself as morally superior and homogenous against the barbaric outsiders ${ }^{4}$ is to strengthen the legitimacy of the State in times of threat. As Homi Bhabha (1996) has shown, the rhetoric of colonialism relies on fetishized discourses which articulate simultaneously the recognition and the disavowal of difference. Their function is to create the fantasy of unity and coherent identities, ultimately providing means of exercizing power. Here, the fantasy of coherence also serves to erase the internal borders erected by the French Republic in its failure to deal with multiculturalism and its diversity (Gallen). Although France is "multicultural in the sense that its population is increasingly diverse" (Simon 14), for French political elites supporting equal opportunities and promoting the values of ethnic communities undermine Republican values and national cohesion. Such attempts are condemned as "communitarianism": a form of cultural separatism seen as a negative consequence of the recognition of cultural differences (Simon 14; also Safran). By contrast, France's national identity, grounded on a commitment to the Jacobin ideal of the democratic nation state, is ostensibly based on the overriding principle of the Republic of Equality. Its assimilationist model, further complicated by the adhesion to laïcité, ${ }^{5}$ presupposes that French citizenship is only available to those who are prepared to renounce their former cultural identity and conform to French Republican values presumed to be neutral and "universal" (Bancel et al. 31-43). This implies the cultural erasure of markers of otherness and-in the name of equality-disregard for inequalities resulting from non-normative identity markers (Bowen 84). Disturbingly, the country's intensified focus on the migrant crisis, radicalization and security were

4 The state of emergency included stripping convicted terrorists born in France with dual citizenship of their French citizenship, therefore excluding them from the ingroup.

5 Laïcité (secularism) refers to the strict legal separation between the religious and civic spheres and is seen as one of the most important foundations of French citizenship. According to laïcité, all conspicuous religious symbols-including headscarves-are banned in official public spaces, including schools. 
also closely connected to the ideologies of far-right parties keen to fuel the strong anti-Muslim sentiment that France has inherited from its colonial era. These concerns further explain the immediate association in France and throughout Europe between the terrorist threat and the migration crisis after the Paris attacks, thus transforming the excluded minority into the enemy within (Nail).

\section{The Politics of Mobility in Contemporaneous French Shakespearean Performance}

We have so far overviewed three recurrent representations of the European crisis pertaining to: (1) achieving coherent identities and unity requires the exclusion of difference; (2) the Other, and the Other in movement, threatens fantasies of coherence; (3) embracing difference leads to crises of leadership at both national and supranational levels. Within this context of heightened identity politics in France and Europe, Jérôme Hankins and Eric Ruf produced two plays by Shakespeare which, I will argue, explore this rhetoric in critical ways.

\section{Jérôme Hankins' The Tempest}

Jérôme Hankins graduated from the Yale School of Drama in 1989 and has worked as a translator and theatre director in France since 1990. He has worked with renowned French directors Antoine Vitez, Jacques Nichet and Christian Benedetti, and lectures on drama at the University of Picardie in Amiens. He is the author of the latest translation into French of Julius Caesar (2002) for the prestigious collection La Pléïade directed by Jean-Michel Déprats. The Tempest was first performed in December 2015 by Hankins' company Outil companie and presented again throughout January 2016-2017. Hankins (44) firmly believes that "il n'y a aucun effort à faire pour que Shakespeare devienne notre contemporain : il est notre contemporain parce qu'il nous comprenait et ces pièces montrent cette compréhension-que nous devons montrer à notre tour." (Making Shakespeare our contemporary takes no effort: he is our contemporary because he understood us and these plays show this understanding-which it is now our job to show.) In choosing to produce The Tempest he thus consciously aimed to reflect on present-day events, explaining in an interview that the play "se nourrit de l'actualité, 'fait boule de neige' des attentats du 13 novembre et de la crise des réfugiés" (takes inspiration from the news, bounces off the attacks of November 13 and the refugee crisis) (Thiébault). The belief that Shakespeare continues to live and relate to our lives today (rather than we attributing meaning to his plays) in both quotations illustrates the strength of the myth. Hankins' critical ambivalence is reflected in the production programme which associates the myth with European identity, but also immediately destabilizes it. Thus, 
Hankins puts forward a post-colonial critique of the history and spatialization of established cultural identity production by situating Shakespeare within a Renaissance context eager to dominate other populations classified as "savage" and "cannibal". He also refers explicitly to the recent killings and the values of universal rights, democracy and freedom of speech under threat:

La Tempête de Shakespeare débute par le chaos général. [...] Cet éclatement de la communauté humaine en proie à la peur de l'inconnu pourrait aussi refléter l'état de nos fragiles démocraties contemporaines. Cri de notre universalité menacée. [...] Les artistes de Charlie Hebdo maniaient avec virtuosité la déformation afin, justement, que nous nous «entendions mieux en nousmêmes. " Lorsque, avec tant d'autres, ils furent assassinés dans leur propre salle de rédaction [...], je me suis dit qu'elle était plus fragile que jamais, notre chance d'être encore libres (en conscience et en actes) d'explorer une pièce qui décrit certes l'être humain comme un monstre, mais aussi comme un «miracle au monde. » Et que par conséquent nous avons plus que jamais aujourd'hui besoin du théâtre où les acteurs trompent l'œil pour mieux montrer. Et voir. (Programme) ${ }^{6}$

Hankins' comments propose politicized techniques of representation which include references to Montaigne's humanist (and also mythic) view on the paradoxical coincidence between chaos and order, ${ }^{7}$ and to the idea that distortion generates clarity. He reproduced this mirror-like effect by using techniques favouring Baroque perceptions whereby "tous les personnages seraient donc vus sous deux angles (au moins)..." (all the characters would therefore be seen from two angles [at least]...) (Hankins 40). He structured the play around the principle of anamorphosis, which he identified as a key technique whereby Shakespeare generates distortion. Anamorphosis is known in art as a deviation from perspective. As opposed from projecting objects in a picture as if they were seen from a widow, in anamorphosis the image is elongated to create an

6 “Shakespeare's Tempest begins with complete chaos. [...] This atomization of human society faced with the fear of the unknown reflects more than ever the fragile state of contemporary society. Our threatened universality crying out. The artists from Charlie Hebdo excelled at distortion so that we could "feel better in ourselves." When, with so many others, they were murdered in their own newsroom [...], I thought that our opportunity to be free (in conscience and in action) to explore a play that, admittedly, describes the human being as a monster, but also as a "miracle to the world", was more tenuous than ever. And that consequently we need today more than ever a theatre where actors deceive the eye to demonstrate better. And see.

${ }^{7}$ Hankins refers to Shakespeare quoting Montaigne in The Tempest. The programme cites: "A universal society of evil and threat." In Book III Chapter IX (461) of his Essays Montaigne suggests that change and disorder are natural phenomena mostly resulting in recovery. 
impression of distortion (as in Holbein's The Ambassadors ${ }^{8}$ for instance). The undistorted image appears as the viewer's gaze is directed to the projection point of the anamorph, allowing the viewer to "'re-form' the object" (Topper 115). With its ability to question perspectives and fixities, anomorphosis disrupts passive everyday perception and discourses, and might therefore encourage critical perspectives on the world. This therefore suggests a useful way of breaking-up or reframing images of experience, as well as of creating different sites of representation of identity. These ideas allude to theoretical spatial fields of critique of identity which are useful to analyse the production. Foucault (24) defined heterotopias as "different spaces" or "other places" whose function is either to "create a space of illusion that exposes every real space, all the sites inside of which human life is partitioned, as still more illusory", or "to create a space that is other, another real space, as perfect, as meticulous, as well arranged as ours is messy, ill constructed, and jumbled" (Foucault 27). A heterotopia is an imaginary space of displacement in which several spaces and slices of time which would normally be incompatible can be juxtaposed within real space, such as the space of the theatre. Like anamorphosis, it has a mirrorlike ability both to reflect yet refract our reality-thus distorting in order to show more clearly, and revealing paradoxes. It therefore functions as a counter-site to represent and contest the space we live in (Foucault 24). Strong critical and political potential can also be found in spaces of liminality. In his work on cultural "in-betweenness", Bhabha ("Frontlines", 2) highlighted the ability of the "third space" to create new, hybrid forms of identity because this space questions the historical and spatial production and meaning of fixed cultural identities. As we shall see next, aspects of these critical spaces were deployed in Hankins' production to reflect and refract practices implicated in the politics of mobility and identity in France and Europe.

According to Hankins, the production was supposed to reflect a fundamental area of human experience: "cette pièce est un laboratoire, une expérience sur ce qui se passe quand on a tout perdu" (the play is a laboratory, an experiment on what happens once we have lost everything) (Thiébault). Caliban's portrayal was key to this interpretation. The character was based on a young homeless Syrian refugee in Malta stating in a 2013 TV interview:

"Ici, personne ne m'aime, alors je parle aux murs, aux chats et à la mer." On croirait entendre Caliban, enfant abandonné sur l'île avant l'arrivée de Prospero et Miranda. Caliban qui sera, dès le début du spectacle, pelotonné dans un drap sur un vieux tapis, ou refugié dans une tente Quechua ("jungle" de Calais) : il est arrivé sur cette île comme à Lampedusa ou à Lesbos. [...] C'est

8 1533, Hans Holbein the Younger. The painting hangs in the National Gallery in London. https://www.nationalgallery.org.uk/paintings/hans-holbein-the-younger-the-ambassadors 
là que Prospero le tient parqué, depuis que l'indigène s'est révélé violeur de femmes. ("No one here loves me, so I talk to walls, cats and the sea." $\mathrm{He}$ sounds like Caliban, a child abandoned on the island before Prospero and Miranda arrived. Caliban who will be, from the beginning of the show, curled up in a sheet on an old carpet, or sheltering in a Quechua-style tent (as in the Calais "jungle"): he arrived on this island in the way refugees did in Lampedusa or Lesbos. [...] It is there that Prospero has been keeping him prisoner, since the native has proved to be a rapist of women) (Hankins 37-38).

The clear connection between Caliban's portrayal and prevalent constructions of mobilities (movement, representations and practices [Cresswell 20]) into France and Europe ${ }^{9}$ is useful as it presents Caliban as a mirror image of hegemonic representations of refugees, including those mediated through our screens and Hankins' former reference to European tropes of colonization. The ambiguity of his portrayal also appears to follow Hankins' baroque, anamorphic model. And yet these representations remain fundamentally problematic since they rely on the ambivalent stereotypical discourse of the Other as both savage and docile, child-like and a sexual predator, helpless and highly sophisticated (Newton 34). These tropes repeat the combined affirmation and denial of difference at the heart of fixed identity discourse and therefore appear to contradict Hankins' desire to question fixities. This contradiction appears to be strengthened by Hankins' argument that Caliban and Prospero share the same discourse, explaining the curious complicity between the two characters (Hankins 39). Arguably, representing the performance of subjective ambiguity in this fashion offers critical advantages: it reveals the way in which stereotypes are involved in the formation of subjectivity. These discourses and their representation both appear to remain firmly caught in hegemonic representations rather than offering alternative narratives. The invocation of the Shakespeare and European fetishes thus initially seem to reinforce colonial hierarchies and therefore to maintain the cohesion of groups.

At the same time, the paradoxical relationship between Caliban and Prospero also provides an active space for the antagonistic interaction of cultures. This process is made evident in the final scene of the play, in which Hankins (43) wanted to highlight Caliban's unresolved situation. As the rest of the characters partake in a Renaissance dance, Caliban "the Cannibal" wraps explosives around himself-in a shocking reminder of the tragedy at the Bataclan. By contrast, Prospero hypocritically asks the audience for indulgence, in an all too familiar public defence of the crisis of leadership. I read this scene

${ }^{9}$ Organised sexual assaults in Cologne and other parts of Germany during the New Year's Eve celebrations of 2015-16 led to a backlash against immigrants and refugees. Hankins' paradoxical portrayal of Caliban as immigrant-victim-savage-rapist is congruent with contemporaneous discourses. 
as a good example of the work of anamorphosis and heterotopia. On the one hand, the scene is a metaphor for the ways in which the post-colonial subject is maintained in positions of Otherness in contrast with the mythology of "civilization". On the other, it violently exposes this process as a construction, revealing the workings of colonialist discourse rather than keeping them invisible. It also articulates difference without pretending that all forms of culture are the same and proffering harmonious collaboration as a solution.

Importantly, Hankins offers powerful alternative narratives of difference by turning the stage into a heterotopic space refracting the empty space of dispossession, and renegotiating constructions of otherness. The performance of The Tempest opens with a drowning. The bare stage features a beach of grey sand with a bunker in the background, introducing past memories and myths of both objectionable and desirable mobilities into France and Europe. A body washed up on the beach lies face down on the stage. This instantly evokes the image of three-year old Syrian boy Aylan Kurdi lying dead on a Turkish beach in September 2015, drowned with his mother and his brother after their boat sank on their way to Greece. Aylan and his tragic death are emblematic of the European migration crisis. Thus presenting the body of the displaced Other in the first image of the production ushers in the metaphor of the practice of mobility and its embodiment from the outset. This metaphor performs a dual critical function. The association of practices of mobility with death and immobility rather than chaos subverts binary models of difference. Representations of "the refugee" as a deviant intruder are also destabilized. True enough, any corpse lying unattended on a beach is soon enough likely to become an intrusive concern... But the body plainly declares the limits of its presumed imposition on society by advertizing the impossibility of its participation. In addition, unlike Aylan, the lifeless body on the beach in The Tempest is anonymous. It only reveals four stretched-out arms and legs covered by a tarpaulin. No further identity markers or any possessions can be made out, paradoxically advertizing the constructedness of difference. Here, then, drawing on the totemic value of Shakespeare to illustrate models of French and European identity helps to reflect the mechanisms that maintain group cohesiveness.

As a result, I believe that the introduction of such contradiction and ambiguity generates a liminal space ushering in a spatial politics of inclusion rather than exclusion. According to Bhabha ("Frontlines", 1), such spaces might have the ability to generate "innovative sites of collaboration and contestation". Such a space of contestation is strengthened in The Tempest through the deployment of strategies of artistic and linguistic anamorphosis used to challenge linguistic hierarchies. In Shakespeare's play the subjugation of Caliban involves learning Prospero's language and culture of colonization and abandoning his own. Whilst a possible way towards resistance could entail rejecting European civilization, here contestation is used to reverse processes of 
exclusion and reshape public perception of contemporary debates. As discussed above, representations of mobilities likewise include metaphors of linguistic and cultural integration vs. alienation, with the language of universalism stressing the incompatibility of difference with equality. The cast for The Tempest includes both professional actors and students from the local university and schools, exhibiting a wide range of experiences and performance skills. The play, performed in French, also incorporates an unexpected linguistic range spanning from songs performed in English to native and local accents including scenes in "picard"-historically the regional language of the Picardie in Northern France where the play was produced. Hankins wanted to reflect the fact that Shakespeare's plays were performed with a range of accents (Thiébault). Linguistic diversity also reflects France's unacknowledged linguistic reality. "Picard" belongs to the regional languages which, whilst being part of the French cultural heritage and important markers of difference, are struggling to retain their identity. In the name of universalism the French Constitution states that "French is the language of the Republic", enshrining standard French as the sole official national language and the symbol of the state and of French identity. Although regional and minority languages are recognized as belonging to the heritage of France, this overlooks the fact that France is inherently linguistically diverse as a result of the presence of regional and minority languages, as well as the languages of migration, and crucially that these languages are living means of communication for multilingual citizens. This debate was prominent in October 2015 when the government's attempt to ratify the European Charter for Regional and Minority Languages (pending since 1999) was rejected for fear that the recognition of particularized rights and identities as opposed to universal, collective ones would cause a break-up of the unity of the nation. Here again, the fetish of universalism simultaneously asserts and fixes the difference of outgroups (Rutherford). By contrast, Hankins' Shakespearean production introduces a liminal space in which hybrid French theatrical cultures and languages explicitly contest fantasies of coherent identities. There is no ambiguity here regarding processes of linguistic identification and recognition. The play offers a polysemic space advertizing its incoherence rather than concealing it under the pretence of unity/exclusion. Thus, the production reverses processes of identification by borrowing from the cultural authority of Shakespeare to reshape public perceptions of current affairs.

Such an emphasis is reflected in available reviews of the plays. For blogger Tata Jacqueline, the production examines 'qu'est-ce que c'est que d'être humain à nos jours? Un tyran, quelqu'un d'aimant, de noble, un monstre, un esclave, un travesti/transexuelle, un être divin, comique, dramatique presque tragique?" (What is it to be human today? A tyrant, someone loving, noble, a monster, a slave, a transvestite/transsexual, a divine being, a comic or dramatic being, or someone who's almost tragic?). The stress here is on the meaning of 
difference and the fluidity and multiplicity of identity. Local students felt that the production speaks especially to today's young people by placing human issues centre-stage to help the young build tomorrow's world (Morain). It is therefore possible to conclude that the production directly confronts narratives surrounding the European crisis and the Paris terrorist attacks in critical ways, showing that cultural icons can be appropriated in an attempt to promote social debates. Critics' comments suggest that the production might resonate with the construction of social and political subjectivities that seek to promote change. Notwithstanding this, it is unlikely to initiate change per se. It conveys conflicting messages about processes of subjectivity formation, and relies on cultural myths that support the underlying status quo.

\section{Eric Ruf's Romeo and Juliet}

Eric Ruf's Romeo and Juliet opened at the Comédie-Française in December 2015. This location is significant as the Comédie-Française and its company are the most prestigious theatrical institutions in France. It is perceived as an index of legitimization and a symbol of French cultural identity and stasis. Actor, director and scenographer Eric Ruf, who has been a member of the ComédieFrançaise since 1993, was appointed as its current administrator in 2014 . He chose to open his first season with Shakespeare because "at the ComédieFrançaise Shakespeare is kind of a French author... when performing world theatre, Shakespeare is an obvious choice" (Ruf). A double process of fetishization of Shakespeare's theatre is at work here: its cultural authority makes it an ideal component of theatrical institutions' repertoires. Consequently, Shakespeare's cultural power grows.

As both director and scenographer, Ruf understands the theatrical space as an interpretative site. Moreover, following Foucault's definition (24), he explicitly conceives of the theatre as a heterotopia (Rivier 13). As a result, his interpretation of Romeo and Juliet is governed by the organizing principles of visual paradoxes and spatial in-betweenness. Ruf is especially interested in the paradoxes within the play, wanting to display the juxtaposition of comedy with tragedy, burlesque with cruelty or pitting Juliet's strength against Romeo's depressive state. Ruf's first concern is to rid the play of the romantic mythology surrounding it and lay bare its fundamental meaning: "une histoire d'amour mais aussi une histoire de haine" (a love story, but also a story about hatred) (Rivier 4). A focal point in the production is the notion that Romeo and Juliet are rebelling against outdated ideologies, such as male domination, religious violence and conflicts between warring groups. Rebellion is directed at topdown, undemocratic authority. Ruf also focuses on character interactions within a context opposing two generations or cultures with highly contrasting beliefs and needs. Rather than representing physical violence, which seeks to contain 
difference, the emphasis is on highlighting antagonistic political identities. Thus, fights and duels are edited out of the plot and replaced by the sudden spreading of blood stains on shirts, stressing the wounding power of social codes.

The metaphor of cultural difference provides the foundations of another heterotopic space, a distorting mirror that reveals the way we hide behind the fiction that cultures can "easily coexist" (Bhabha "Frontlines" 209). Ruf builds a site of liminality that highlights uneven and conflictual identities tentatively allowing the construction of cultural difference. In an attempt to distance the audience from well-known, sentimental interpretations of the play, the plot is relocated to Sicily in the 1930s - an "in-between" intended to be all at once visually neutral, contemporary and historically distant. The cultural backdrop of poverty, religiosity and civil war best conveys, Ruf believes, the dangerous space of murder and vendetta in which he situates Romeo and Juliet. It also provides an intersection of space and time allowing the heterotopia to "function at full capacity" (Foucault 26). The atmosphere of threat is conveyed through the building of a flexible stage set denoting the exceptionally high walls of a crumbling, oppressively hot Mediterranean city. These walls are in constant movement, forming a centrifugal maze of narrow alleyways and windows with occluded view. They are simultaneously isolating and penetrable-like a heterotopia. Ruf's aim is to shock the audience into a realization of the risks and possibilities inherent in incommensurable cultural conflict: "l'histoire est certes tragique, mais avant de mourir, il faut vivre, semble nous souffler Shakespeare" (the story is certainly tragic, but before we die, we have to live, seems to suggest Shakespeare) (Demarthon). This paradox is powerfully represented in the staging of Act II scene 2, traditionally known as the balcony scene. Suliane Brahim (Juliet) performs whilst precariously standing on a narrow stone shelf over a thirteen-foot drop, representing the remains of a former balcony. Ruf's intention is that:

Cela m'intéressait que les spectateurs découvrent qu'en réalité le balcon était tombé ! D'autant qu'avec une simple corniche, si Juliette tentait en effet de fuir, elle était coincée. Prise au piège dans cet espace-là comme un sentiment fuyant, ce serait du point de vue interprétatif, explicite. Roméo [...] la verrait comme l'on voit un somnambule auquel on doit parler avec précaution et raccompagner à son lit doucettement, de peur qu'il ne tombe. Ce danger réciproque-fuir sans tomber et empêcher quelqu'un de tomber-devrait, selon moi, tendre la scène. [...] Dans cette scène extrêmement connue, Juliette apparaît au balcon et plus personne n'écoute. Le fait que le lieu soit dangereux, cela rend les spectateurs actifs car ils s'interrogent : va-t-elle tomber ? (Rivier 6-5). ${ }^{10}$

${ }^{10}$ I wanted the audience to find out that in reality the balcony had collapsed! Especially with a simple cornice, if Juliette tried indeed to flee, she was stuck. From an interpretive point of view, it would be clear that she was trapped in this space like 
What might happen in this space of risk-taking is different and unpredictable. It is a space of intervention (a third space) between cultures-between the culture of traditional values and the culture of rebellion-rather than a fixed space. A number of critics disapproved of this scene for distracting the audience from Shakespeare's lines for fear of an accident (Di Gregorio). Such an attempt to re-essentialize Shakespeare's play by returning it to the fiction of origins seems meaningful, as the critics' resistance may confirm that the production has tentatively opened a new site of renegotiation of meanings.

The production offers other spaces of intervention which are less controversial. Ruf turns the heterotopic space of (very) public toilets into the loci of Romeo and Juliet's romantic meetings. The final scene of the play is also distorted. In V. 3 Ruf made Juliet's tomb into a replica of the Capuchin Catacombs of Palermo, in which naturally-preserved mummies dressed in sumptuous clothing (therefore presenting them as socially-coded) are displayed in niches along the walls of the cemetery (Gervot). The play ends with the death of the rebellious Juliet. This is a striking intervention: Ruf rejects the idea that Juliet's sacrifice should lead to any form of reconciliation, mirroring the contemporaneous response of violence by more violence. Turning Juliet's death into the natural order of things, as it were, means that the play ends in pure tragedy as no kind of order can be restored in the end-again, reflecting a fundamental crisis in (national and supranational?) leadership. In addition, the living are prevented from interacting with the dead. The heterotopic space of the cemetery itself is disrupted, offering, through the medium of theatre, a new space of alterity and otherness. This may further contribute to shattering illusions of harmonious integration. It is Ruf's belief that the production addresses current issues: "ce que [Shakespeare] soulève est si contemporain, et on ne peut qu'être admiratif de sa grande polysémie" (what [Shakespeare] raises is so contemporary, and one can only admire his great polysemy) (Grangeray). Here again, the belief in the clarity of Shakespeare's intention and that his plays transcend history makes them into myths (Bourdieu).

The majority of public responses to the production confirm that Ruf's intention to reflect current affairs was fulfilled. Critics highlight the parallels between Ruf's Sicilian-Shakespearean space, contemporary intolerance (Gomes) and today's upsurge of patriarchal, sexist violence (Grapin). Many reviewers welcome Ruf's unconventional approach. A minority, however, deplore his

a fleeting feeling. Romeo [...] would see her as one sees a somnambulist that must be approached with caution and taken back to bed very carefully, lest they fall. This reciprocal danger-fleeing without falling and preventing someone from fallingshould, in my opinion, dominate the scene. [...] In this extremely well-known scene, Juliette appears on the balcony and no one is listening. The fact that the place is dangerous makes the spectators active because they ask themselves: will she fall? 
interventions on Shakespeare's text or the thwarting of audience expectations with the balcony scene (Di Gregorio; Grapin; Rivier). The choice of FrançoisVictor Hugo's translation is occasionally considered to be a poor choice: despite Ruf's inclusions of contemporary language and diction, its romantic character is said to suppress the earthiness of Shakespeare's language (Capron). For Bouthors, the play is excessively distanced from reality following the attacks of 13 November: the audience is said to need a more robust message. For David, the stereotypical images of 1930s Italy tone down Ruf's emphasis on identity politics. By contrast, others feel that highlighting the links between power and prejudice is an inspired, socially-committed intention that gives new life to Romeo and Juliet and makes it uniquely relevant today (Chevilly; Gomes). Armelle Héliot, the French daily Le Figaro's influential critic, argues that the production both speaks to the audience at a personal level and has the power to bring people together. Ruf's novel interpretation of Shakespeare's plot is also praised for providing two constructive social messages in winter 2015: individuals matter more than the group; the theatre transcends death and fear (Barbier). In an interview actor Jérémy Lopez, who plays Romeo, also stressed the relevance of Shakespeare's play to help process the horror of the Bataclan massacre: although we are aware that Romeo and Juliet will end in horror, we must suspend disbelief awhile in order never to become immune to that kind of horror-sentiments which all noticeably reflected national calls for unity and defiance in the face of terror in winter 2015 ("Les Captifs amoureux").

Significantly, divisions of opinion among critics respond to Ruf's paradoxical construction of his production. Disagreement reflects public debate and appears to support the claim that the production potentially opened new sites of negotiation of meaning and identities. It would follow that the potential threat to some certainties would be perceived by some as deeply destabilizing. I might therefore argue that the alternative subjectivities that emerge offer a space from which resistance to some hegemonic narratives of identity and mobilities can surface (Bhabha "Culture"). Some of these are interpreted here as potential threats to the Shakespeare myth, even though Ruf's appropriation of the playwright's authority entails strengthening of this myth.

Is it possible to conclude from the above analyses that Hankins' and Ruf's productions offered productive spaces of intervention where meaning can be displaced and renegotiated (Bhabha "Culture")? The spaces of liminality they created have, without a doubt, resulted in underscoring the politics of mobility and hegemonic practices in the construction of identities in crisis. Understanding subjectivity as multidimensional offered a very useful notion of identification as constructed, thus avoiding essentialist polarities between the dominant and the dominated. The productions' main take-home message for reviewers was their effectiveness in highlighting contemporary social and political crises following 
terrorist attacks. Both productions thus successfully commented on sociocultural differences, injustices and marginalization (Kushner). The disruption introduced by innovative spaces of confrontation was also illustrated by critics' discomfort in the face of Ruf's scenography. It might also be argued that the strength of Jérôme Hankins' production of The Tempest was to cast light on the human cost of mobility and the political cost of imagined communities. Similarly, the loss of financial backing for the NYC play partly revealed the process of concealment. However, it must be noted that the production was backed financially by other agents with their own specific agenda. This exposes this particular Shakespearean event as a cultural and economic product with ideological added value.

I would therefore hesitate to claim that the productions constitute counter-narratives able to transform society. This is because they continue to accommodate the difference of cultures within essentialist and universalist frameworks. I have shown that both directors and critics systematically associate Shakespeare's plays and thoughts with the productions. Some negative reactions to Ruf's production result from fears that the Shakespearean fetish might be undermined. Overall, the act of performing Shakespeare's plays as markers of contemporary social and political concerns relies on the conviction that his drama transcends history and is a symbol of social cohesion. Of especial interest is the close association between Shakespeare's theatre and intentions, and specific ideological interests. This is shown through the belief that his work, and by implication, Shakespeare himself, represent something more than the stories that they tell. The principle behind this process is that mythical objects aligned with discourses constituting group identity as a unified political, historical, geographical and cultural entity assume notions of individual agency. I referred to the "Marche républicaine" earlier. On the occasion of the rally an image released on Facebook showed Shakespeare's portrait with the caption in English "to be or not to be Charlie". The association of Shakespeare's name-and presumed opinion-with a movement that benefits State narratives is fascinating. This image competed with other totems of national identity based on the iconographic symbols of the French republic such as Marianne and the Tricolour. This is also replicated when, as shown above, directors and critics claim that Shakespeare's plays are especially resonant with contemporary society, that he "understands us". Ruf further associates Shakespeare with national identity by claiming that he is "kind of French". However, the belief in Shakespeare's congruence conceals that his name is unrelated with French national values per se. Through decades of ascribing characteristics to his theatre that are attached to shared identities, it has acquired considerable social and cultural value giving it the quality of myth. The belief that Shakespeare speaks to us today disregards the historical and social conditions of the plays' own production. It ignores the fact that Shakespeare's plays are sites where cultural 
production constantly occurs and new social and political means are produced and communicated (Barthes; Bourdieu). The processes whereby the playwright's authority is discursively constituted and the result of institutional practices committed to furthering the existing social order also remain invisible. If Shakespeare has become and is used as a sacred myth that mirrors the myths associated with the nation, then his name and his theatre fulfil very specific ideological needs which go hand in hand with the valorization of accepted culture, especially high culture. As myths work to hide the traces of their own determinate historical production, Shakespeare's plays are important because they help maintain social hierarchies and specific politics of representation. This has implications for Ruf's and Hankins' productions. Under the guise of offering critical heterotopias and liminal spaces, the metaphors of rebellion and difference are likely to serve to maintain myths built around the nation and the politics of mobilities. Hankins' production, for instance, has shown that the ambivalence in the representation of Caliban partly fed into the power of colonial discourse, which relies on a contradictory mode of representation. By virtue of being staged by and at the Comédie-Française, Ruf's play ultimately represents and reproduces the values of high culture ${ }^{11}$ and of the French republic.

The individuation of myths also makes it unclear who is involved in power relations, since borders, boundaries and power networks appear transparent. There is therefore little sense of historical, ideological and theoretical continuities and hierarchies, which prevents any investigation of the real motivations behind cultural production, mobility as well as social and cultural exclusions. The latter are seen in a vacuum. In addition, it is also necessary to consider that Shakespeare's extraordinary presence in Europe (and elsewhere) is also about the fact of movement rather than just its causes or consequences (Cresswell 22). Shakespeare's mobility itself is as much productive of social relations and produced by them as it can represent them. This entails particular politics, economics, geographies but also hierarchies of production and mobility, which in the case of Shakespeare in Europe, should not be ignored.

For Barthes ("Myth Today", 57), myth is always depoliticized speech: its role is to pass off a socially-constructed reality as natural and innocent. This applies to politics of representations and self-definitions, which in the case of nation building or Shakespeare, can often be ignored. Let's not forget that, irrespective of the myth, behind the nation and the supranational lay the subject and its discursive constructions. Invocations of Shakespeare's theatre, therefore, also serve to legitimize European and French societies in accordance with a climate that promotes social and cultural stasis. Its ultimate role is to

${ }^{11}$ Audiences tend to be homogeneous and largely consist of highly-educated, middleclass Parisians. 
strengthen an underlying sense of collective being. This interpretation is useful to explain the paradoxical popularity of Shakespeare in France and elsewhere. It also serves to highlight one of the most profane (and concealed) motivations behind the always-increasing circulation of Shakespeare knowledge and performance within the European Union and beyond.

To some extent Jérôme Hankins and Eric Ruf's productions confirm this model. If, as claimed by reviewers, they can both speak to individuals and bring people together, then this would suggest that the Shakespeare myth may be invoked to strengthen a sense of collective being. Importantly, this discourse has also been complicated since both directors have also successfully appropriated Shakespeare's cultural authority to create heterotopic spaces, and partly to challenge the construction of political subjectivities, whatever the impact of their intervention may be. Barthes' claim (Mythologies, 229) that myths are on the side of the state-whether conservative or progressive-therefore appears to be partly borne out by the two productions examined in this essay. Whilst their appropriation of the Shakespeare myth in these productions is unlikely to create radical social change, it has shown its potential for encouraging meaningful debate, which is a significant achievement.

\section{WORKS CITED}

Anderson, Benedict. Imagined Communities: Reflections on the Origin and Spread of Nationalism. London: Verso, 1983.

Bancel, Nicolas, Pascal Blanchard and Sandrine Lemaire. La Fracture coloniale: la société française au prisme de l'héritage colonial. Paris: La Découverte, 2005.

Barbier, Christophe. "Les Amants de Vérone: Juliette plus héros que Roméo." L'Express.fr. 6 December 2015. 12 June 2017. <https://www.lexpress.fr/ culture/scene/les-amants-de-verone-juliette-plus-heros-que-romeo_1741756.html>.

Barthes, Roland. Mythologies. Paris: Seuil, 1957.

- - - "Myth Today." Visual Culture: The Reader. Eds. Jessica Evans and Stuart Hall. London: SAGE Publications, 1999. 51-58.

Bhabha, Homi K. "Culture's in Between." Questions of Cultural Identity. Eds. Stuart Hall and Paul Du Gay. London: Sage Publications, 1996. 53-60.

- - - "Frontlines/Borderposts." Displacements: Cultural Identities in Question. Ed. Angelika Bammer. Bloomington: Indiana University Press, 1994. 269-272.

Beckett, Lois. "Trump As Julius Caesar: Anger Over Play Misses Shakespeare's Point, Says Scholar." The Guardian 12 June 2017. 12 June $2017<\mathrm{https} / / / \mathrm{www}$. theguardian.com/culture/2017/jun/12/donald-trump-shakespeare-play-juliuscaesar-new-york>.

Bigo, Didier, Eveline Brouwer, Sergio Carrera, Elspeth Guild, Emmanuel-Pierre Guittet, Julien Jeandesboz, Francesco Ragazzi and Amandine Scherrer. "The EU Counter-Terrorism Policy Responses to the Attacks in Paris: Towards an EU Security and Liberty Agenda." CEPS Paper in Liberty and Security in 
Europe 81 (2015). 15 October 2018. <https://www.ceps.eu/system/files/LSE81 Counterterrorism.pdf $>$.

Boitiaux, Charlotte. “À Munich, Valls joue la fermeté et dit 'stop' à l'afflux de réfugiés en France." France24. 16 February 2016. 17 October 2018. <https://www. france24.com/fr/20160216-munich-valls-refugies-migrants-merkel-france-terreasile-france-relocalisation>.

Bourdieu, Pierre. The Rules of Art. London: Polity Press, 1966.

Bouthors, Jean-François. “Tchekhov et Roméo et Juliette, après le 13 novembre.” Esprit. December 2015. 3 July 2017. <https://esprit.presse.fr/actualites/jean-francoisbouthors/tchekhov-et-romeo-et-juliette-apres-le-13-novembre-40098>.

Bowen, John R. Why The French Don't Like Headscarves. Princeton: Princeton University Press, 2007.

Buonano, Laurie. "The European Migration Crisis." The European Union in Crisis. Ed. Desmond Dinan, Neill Nugent and William E. Paterson. London: Palgrave MacMillan 2017. 100-130.

Capron, Stéphane. "Eric Ruf fait revivre Roméo et Juliette à la Comédie-Française dans une version romantique". Sceneweb.fr. 8 December 2015. 3 July 2017. $<$ https://sceneweb.fr/jeremy-lopez-et-suliane-brahim-dans-romeo-et-juliette-deshakespeare/>.

Chevilly, Philippe. “'Roméo et Juliette', des amants ravageurs au Français”. Les Echos. 14 December 2015. 3 July 2017. <https://www.lesechos.fr/14/12/2015/LesEchos/ 22086-045-ECH_--romeo-et-juliette----des-amants-ravageurs-au-francais.htm>.

Commission européenne. "Immigration en Europe (UE): \#RefugeeCrisis, la crise des réfugiés." Représentation en France. 18 October 2018. 18 October 2018. $<$ https://ec.europa.eu/france/news_focus_migration_fr $>$.

Corey, Frederick C. "Performance and Social Change." Text and Performance Quarterly 35.1 (2015): 1-3.

Cresswell, Tim. "Towards a politics of mobility." Environment and Planning D: Society and Space 28 (2010): 17-31.

David, Gwénola. "Roméo et Juliette”. La Terrasse 239. 21 December 2015. 4 July 2017. $<\mathrm{https}$ ://www.journal-laterrasse.fr/romeo-et-juliette-16/>.

Demarthon, Jacques. "Eric Ruf réveille la flamme de 'Roméo et Juliette' à la Comédie Française.” Le Point.fr. 8 December 2015. 4 July 2017.<https://www.lepoint.fr/ culture/eric-ruf-reveille-la-flamme-de-romeo-et-juliette-a-la-comedie-francaise08-12-2015-1988118_3.php>.

Di Gregorio, Ulysse. “'Roméo et Juliette', mise en scène d'Eric Ruf à la ComédieFrançaise." Un Fauteuil pour l'Orchestre. 16 December 2015. 4 July 2017. $<$ http://unfauteuilpourlorchestre.com/romeo-et-juliette-mise-en-scene-deric-rufa-la-comedie-francaise/>.

Durkheim, Emile. The Rules of Sociological Method. 2nd ed. New York: The Free Press, 1938.

European Union. "The EU Motto.” 20 October 2017. 27 October 2018. <https://europa. eu/european-union/about-eu/symbols/motto_en>.

Fayard, Nicole. The Performance of Shakespeare in France since the Second World War: Re-Imagining Shakespeare. New York etc.: Edwin Mellen Press, 2006. 
Foucault, Michel. "Of Other Spaces." Trans. Jay Miskowiec. Diacritics 16.1 (1986): 22-27. Originally published as "Des Espace Autres (Conférence au Cercle d'études architecturales, 14 March 1967)." Architecture, Mouvement, Continuité 5 (1984): 46-49.

Gallen, Claire. "Charlie Hebdo, radicalisation marginale ou raté de l'intégration?" Le Point.fr. 13 January 2015. 10 September 2015. <http://www.lepoint.fr/societe/ charlie-hebdo-radicalisation-marginale-ou-rate-de-1-integration-13-01-20151896137_23.php>.

Gervot, Christophe. “'Roméo et Juliette’ à la Comédie-Française: précipice amoureux”. Fragil. 26 August 2016. 19 July 2017. <https://www.fragil.org/romeo-etjuliette-a-la-comedie-francaise/>.

Gomes, Paula. "'Romeo et Juliette' de William Shakespeare, mise en scène d'Erif Ruf à la Comédie-Française." Théâtre-Actu. 13 December 2015. 19 July 2017. $<\mathrm{http}$ ://theatreactu.com/romeo-et-juliette-de-william-shakespeare-mise-en-scenederic-ruf-a-la-comedie-francaise/>.

Grangeray, Emilie. "Eric Ruf: 'Roméo et Juliette n'est pas la bluette que l'imaginaire collectif a façonnée'." Le Monde.fr. 4 December 2015. 19 July 2017. <https:// www.lemonde.fr/m-actu/article/2015/12/04/eric-ruf-romeo-et-juliette-n-est-pasla-bluette-que-1-imaginaire-collectif-a-faconnee_4824436_4497186.html>.

Grapin, Jean. "Roméo et Juliette... La mise en scène d'Eric Ruf esquive des pièges de mièvrerie romantique." La Revue du spectacle. 18 December 2015. 19 July 2017. <https://www.larevueduspectacle.fr/Romeo-et-Juliette-La-mise-en-scened-Eric-Ruf-esquive-des-pieges-de-mievrerie-romantique_a1505.html>.

Greene, Maxine. Releasing the Imagination. Essays on Education, the Arts, and Social Change. San Francisco: Jossey-Bass, 1995.

Hankins, Jérôme. "Mettre en scène la Tempête. Ou défier les logiques brisées de la dramaturgie Shakespearienne." Ed. Valérie Toranian. Revue des deux mondes (May 2016): 36-45.

Héliot, Armelle. "Roméo et Juliette: une féerie tragique." Blog.lefigaro.fr. 8 December 2015. 19 July 2017. <http://blog.lefigaro.fr/theatre/2015/12/romeo-et-julietteune-feerie-t.html $>$.

Hollande, François. "Hommage national: le texte intégral du discours de François Hollande, Repéré par Vincent Manilève." Slate.fr. 27 November 2015. 23 October 2018. <http://www.slate.fr/story/110717/hommage-national-textediscours-francois-hollande>.

Kushner, Tony et al. "How Do You Make Social Change?" Theater 31.1 .3 (2001): 62-93.

Landy, Robert and David T. Montgomery. Theatre For Change: Education, Social Action and Therapy. Basingstoke: Palgrave Macmillan, 2012.

Laughland, Oliver. "Muslim Americans on Trump's Travel Ban: 'We Live as SecondClass Citizens'." The Guardian. 27 June 2018. 27 June 2018. <https://www. theguardian.com/us-news/2018/jun/26/muslim-americans-trump-travel-ban>.

Le Blog de Tata Jacqueline. "Tempest de W. Shakespeare, création de l'Outil Compagnie, nouvelle traduction et mise en scène pas Jérôme Jankins." 23 January 2015. 9 July 2017. <https://tatajacqueline.wordpress.com/2015/ 
01/23/tempest-de-w-shakespeare-creation-de-loutil-compagnie-nouvelle-traductionet-mise-en-scene-par-jerome-hankins/>.

Lopez, Jérémy. "Les Captifs amoureux.” Mordue de théâtre. 5 October 2017. 22 November 2018. $<$ https://mordue-de-theatre.com/tag/jeremy-lopez/>.

Montaigne, Michel Arouet de. Essais. Ed. M. J.-V. Le Clerc. Vol. 3. Paris: Garnier Frères, 1866.

Morain, Odile. “'Tempest': Jérôme Hankins revisite Shakespeare avec des jeunes d'Amiens." Culturebox. Francetvinfo.fr. 28 January 2015. 9 July 2017. <https:// culturebox.francetvinfo.fr/theatre/theatre-contemporain/tempest-jerome-hankinsrevisite-shakespeare-avec-des-jeunes-d-amiens-210541>.

Nail, Thomas. "A Tale of Two Crises: Migration and Terrorism after the Paris Attacks." Studies in Ethnicities and Nationalism 16.1 (2016): 158-167.

Pagden, Anthony. The Idea of Europe. From Antiquity to the European Union. Cambridge: Cambridge University Press, 2002.

Rivier, Estelle. "Du balcon de Roxane à celui de Juliette. Entretien avec Eric Ruf, acteur, metteur en scène, scénographe et administrateur de la Comédie-Française." Shakespeare en devenir, Les Cahiers de La Licorne, L'Oeil du Spectateur 9 (2015). 30 October 2018. <http://shakespeare.edel.univ-poitiers.fr/index. php?id=1079>.

Ruf, Eric. "Introduction par Eric Ruf." British Embassy Paris. 2016. 10 July 2017. $<$ https://soundcloud.com/ukinfrance/1-eric-ruf-intromp3 $>$.

Rutherford, Jonathan. "The Third Space: Interview with Homi Bhabha." Identity, Community, Culture, Difference. Ed. Jonathan Rutherford. London: Lawrence and Wishart, 1990. 207-221.

Safran, William. "State, Nation, National Identity, and Citizenship: France as a Test Case." International Political Science Review 12.3 (1991): 219-38.

Simon, Patrick. "French National Identity and Integration: Who Belongs to the National Community?" Rethinking National Identity in the Age of Migration: The Transatlantic Council on Migration. Ed. Demetrios G. Papademetriou. Washington: Migration Policy Institute and Bertelsman Stiftung Verlag, 2013. 171-188.

Thiébault, Estelle. “La Tempête' retrouve les projecteurs à Amiens." Le Courrier Picard. 20 January 2016. 10 July 2017. <http://www.courrier-picard.fr/archive/ recup $\% 3 \mathrm{~A} \% 252$ Fregion $\% 252$ Fla-tempete-retrouve-les-projecteurs-a-amiensia167b0n709154>.

Topper, David. “On Anamorphosis: Setting Some Things Straight.” Leonardo 33.2 (2000): 115-124.

Wahlquist, Calla and Lois Beckett. "'This is Violence Against Donald Trump': Rightwingers Interrupt Julius Caesar Play." The Guardian. 17 June 2017. 19 June 2017. <https://www.theguardian.com/us-news/2017/jun/17/trumpsupporter-interrupts-controversial-julius-caesar-play-in-new-york $>$. 